\title{
Publisher Correction: Accelerating functional gene discovery in osteoarthritis
}

Natalie C. Butterfield (D), Katherine F. Curry, Julia Steinberg (D), Hannah Dewhurst, Davide Komla-Ebri(D), Naila S. Mannan, Anne-Tounsia Adoum, Victoria D. Leitch (D, John G. Logan, Julian A. Waung, Elena Ghirardello, Lorraine Southam, Scott E. Youlten (1), J. Mark Wilkinson (1), Elizabeth A. McAninch (1), Valerie E. Vancollie (D), Fiona Kussy, Jacqueline K. White, Christopher J. Lelliott (D, David J. Adams (D, Richard Jacques (D, Antonio C. Bianco, Alan Boyde (1), Eleftheria Zeggini (1), Peter I. Croucher (1), Graham R. Williams (1) \& J. H. Duncan Bassett (1)

Correction to: Nature Communications https://doi.org/10.1038/s41467-020-20761-5, published online 20 January 2021.

The original version of this Article contained private information in the Data Availability statement, which was used by reviewers to access Proteomics datasets. This information has now been removed from both the PDF and HTML versions of this article.

Published online: 28 May 2021

\footnotetext{
(c) Open Access This article is licensed under a Creative Commons Attribution 4.0 International License, which permits use, sharing, adaptation, distribution and reproduction in any medium or format, as long as you give appropriate credit to the original author(s) and the source, provide a link to the Creative Commons license, and indicate if changes were made. The images or other third party material in this article are included in the article's Creative Commons license, unless indicated otherwise in a credit line to the material. If material is not included in the article's Creative Commons license and your intended use is not permitted by statutory regulation or exceeds the permitted use, you will need to obtain permission directly from the copyright holder. To view a copy of this license, visit http://creativecommons.org/licenses/by/4.0/.
}

(C) The Author(s) 2021 